UDC 502:504

Angelina V. Chugai, $\mathrm{PhD}$ (geography), Ass. Prof., Dean of Nature Protection Faculty ORCID: orcid.org/0000-0002-8091-8430e-mail: avchugai@ukr.net

Tamerlan A. Safranov, Doctor of Science, Prof., Head of Department of Environmental Science and Environmental Protection

ORCID: orcid.org/0000-0003-0928-5121 e-mail: safranov@ukr.net

Odessa State Environmental University, Odessa, Ukraine

\title{
A TECHNOGENIC LOAD ON THE ENVIRONMENTAL COMPONENTS DURING THE FORMATION AND ACCUMULATION OF THE WASTE IN THE NORTH-WESTERN BLACK SEA REGIONS
}

\begin{abstract}
The amount of the production and consumption waste generated and accumulated in a certain territory (in the region) can be considered as one of the indicators of a technogenic load on the environmental components. The processes of formation and accumulation of various wastes pose a threat to a state of all environmental components. The formation and, especially, the accumulation of production and consumption waste inevitably contaminate the soil cover.

The problem of inefficient waste management is typical for the regions of Ukraine, and therefore the purpose of the work is to assess a level of a technogenic load on the environmental components by the indicators of the formation and accumulation of production waste and the consumption in the regions of the Northwest Black Sea. To evaluate and analyze a level of a technogenic load on the environment based on the principle of calculating a technogenic load module it is proposed to determine a module of a technogenic load on the geological environment, ie the most vulnerable component of the environment.

It is established that the greatest load in the territory of the North-Western Black Sea is in the Mykolaiv region (due to industrial waste). The amount of the generated and accumulated waste exceeds the corresponding figures in the Odesa and Kherson regions. More than 95\% are class IV hazardous waste. In almost all regions of the Northwest Black Sea, there has been a tendency of increasing a load, primarily due to the increased accumulation of the waste.

It is suggested to determine a module of a technogenic load on the geological environment according to the waste generated and accumulated in the region.
\end{abstract}

Keywords: a technogenic load module; geological environment; waste; formation; accumulation

(C) A. V. Chugai, T. A. Safranov, 2020 


\section{Introduction}

The processes of forming and accumulating the various wastes pose a threat to a state of all environmental components. At the sites of landfills (landfills), harmful substances enter the air pool, pollute fertile soils, surface and groundwater, and also pose a threat to a sanitary and epidemiological state of the surrounding settlements. Taking into account that in the regions of Ukraine the predominant method of handling solid household waste (SHW) is its removal and disposal at landfills (landfills), the absolute majority of which do not meet the environmental safety requirements, the processes of physical, chemical and biological pollution, in particular, the geological environment (GE) will be enhanced.

The GE is the upper part of the lithosphere, which is considered as a multicomponent system, which is influenced by human engineering and economic activity, and, in its turn it fully determines this activity [1]. In the Environmental Encyclopedia [2], the GE is a multicomponent dynamic complex organized natural system (rocks, soils, sediments, groundwater, natural gases), which is characterized by the presence of geophysical and geochemical fields and interacts with the elements of landscape, atmosphere, surface waters and is affected by technogenic activities. According to this definition fertile soils are included into the GE; only natural gases and non-hydrocarbon fluids are included into the GE componenets. The GE "interacts with the elements of the landscape, the atmosphere", but a ground part of the atmosphere is a part of the landscape.

The issue referring to the GE upper boundary is no less difficult, because many researchers include not only rocks, but also fertile soils, surface water and biota into the concept of "the geological environment". Therefore V.T. Trofimov and others [3] proposed the term "a surface part of the lithosphere" (LSP), excluding surface waters and, in certain situations, fertile soils from it instead of the term "the geological environment". In their interpretation, the upper boundary of the LSP usually extends along the sole of the humus layer of the fertile soil. If we consider the Earth's soil shell (the pedosphere) as a separating shell - a battery and a source of energy for bionites, then as a rule, fertile soils fall out of the GE (it should be recalled that fertile soils are subaerial, and bottom sediments are subaltern, but the latter are not generally referred to the GE). However if soil is considered as a geochemical barrier to the migration of pollutants, it is a part of the GE. If we consider fertile soil as mineral-organogenic rock acting as the first geochemical barrier to the migration of technogenic Ps or the environment for the exogenous processes development, it must be included in the object of ecological geology.

Therefore taking into account the fact that during forming and, especially, accumulating the production and consumption waste, a soil cover is inevitably contaminated, it is advisable to consider fertile soils as a component of the GE in this work.

The amount of production and consumption waste generated and accumulated in a certain territory (in the region) can be considered as one of the indicators of a technogenic load on the GE.

In the Odessa region, the facilities for the utilization and disposal of hazardous production wastes were created and are operating. But they are not enough. The system of hazardous waste collection is not developed in the rural areas. Also a serious problem is the problem of storage and safe handling of the unsuitable pesticides that have remained on the territory of the region since the Soviet time [4]. 
About 6.1 million $\mathrm{m}^{3}$ of SHW are produced annually in the Odessa region. According to the Department of Ecology and Natural Resources of the Odessa Regional State Administration, there are 608 landfills occupying about 1300 hectares in the region. Most of them are in poor condition and are operating in violation of the environmental llaws and the sanitary and epidemiological safety requirements. An assessment of whether the territory of the Odessa region is favorable for the placement of SHW landfills has been made by physical-geographical, engineeringgeological, hydro-geological and technogenic indicators, but the obtained results do not allow to select a specific site for SHW landfill landing [5].

The main spheres where hazardous waste is actually generated in the Mykolaiv region include metallurgy, machine building, shipbuilding, food processing, leather processing, water utilities, agricultural enterprises, medical institutions. As for 2017 the Mikolaev alumina plant was the largest source of the waste generation among the enterprises in the region [6].

In the territory of the Kherson region there are 100 waste generation facilities and 8 waste treatment and disposal facilities. A critical situation has emerged in the area of SHW management. Each year more than 250,000 tonnes of SHW are produced in the region. According to the inventory of the landfill sites, 329 such sites are located in the territory of the region, and only 73 of them are certified and 77 enterprises are operated with the documentation for the right to use the land. Also there are 1921,804 tonnes of unsuitable pesticides on the territory of the region, and 1887,436 tonnes of them are ownerless [7].

Many issues have been devoted to the waste management and consumption in the regions of the North-Western Black Sea. Thus in the work [8] a general characterization of the problem of landfills for the Odessa region is presented. The authors formed a set of indicators on the location of SHW. Based on the cluster analysis, zoning of the territory of the Odessa region according to the indicators of the SHW locations was carried out. It is determined that the problem of inefficient waste management is typical for the regions of Ukraine. Also in the work [9] a classification of the individual components of a hazardous part of the SHW was proposed. The authors think that it will prevent a negative impact of this type of the waste on the environment and transform a large part of it into the state of secondary material resources. One of the main documents regulating the management of SHW in the Odessa region is a project of "The program of solid household waste management in the Odessa region for 2018-2022" [10]. Its main purpose is to ensure an appropriate network of waste disposal facilities as well as bringing existing facilities into compliance, where appropriate, and closing the facilities that are not in compliance with the standards and pose a significant risk to human or environmental health.

The Regional Program of SHW Management in the Mykolayiv region for the period up to 2020 is in operation.

In the works $[11,12]$ the problems of household waste utilization in the Kherson region including the countryside were investigated.

An analysis of the environmental impact of the production and consumption waste on the environment of the North-Western Black Sea regions is presented in the work [13].

The purpose of this work is to assess a level of a technogenic load on the GE by the indicators of forming and accumulating the production and consumption waste for the regions of the North-Western Black Sea. 


\section{Research methodology}

To evaluate and analyze a level of a technogenic load on the geological environment, the principle of calculating a technogenic load module, which is defined as a sum of weight units of all types of wastes (solid, liquid, gaseous) of the industrial, agricultural and municipal objects for a time interval -1 year, applied to the area of the administrative district or region within which these objects are located and it is measured in thousand tons $/ \mathrm{km}^{2}$ per year [14]. The authors proposed to determine individually a technogenic load module on the GE $\left(M_{G E}\right)$ by the indicators of the waste generated and accumulated in the region. This approach was implemented in the estimation of a technogenic load on the air basin and water bodies of the regions of the North-Western Black Sea, for example in the works $[15,16]$.

\section{Research results}

According to the Regional reports, Ecological passports of the region, as well as the materials of the State Statistics Service of Ukraine [17] we analyzed the information on the volumes of forming and accumulating the waste in the regions of the NWBS.

Figure 1 shows the dynamics of the waste generation in the Odessa region. As it can be seen the maximum generation was recorded in 2012. However there is a general tendency to reduce the amount of the generated waste. Also almost $99 \%$ of the generated waste is class IV hazardous waste.

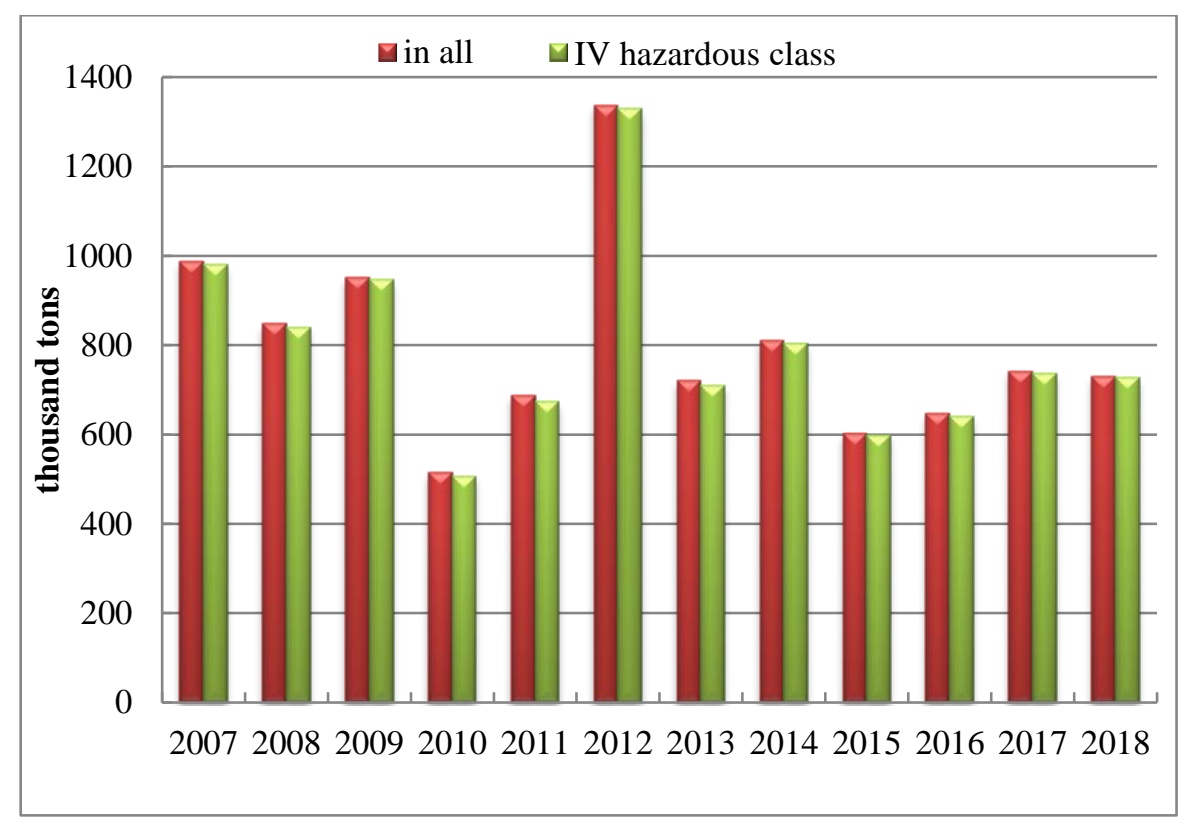

Fig. 1 - The dynamics of the waste generation in the Odessa region in 2007-2018

The information about the waste accumulated in the Odessa region was available from 2010 to 2015 . In 2014-2015 the amount of the generated waste was no more than $10 \%$ of the accumulated waste. However the amount of accumulated waste each year may increase or remain constant. In 2014-2015 this value remained almost unchanged. Therefore in the future we will assume the data of 2015 as an indicative 
value of the accumulated waste amount in 2016-2018, namely 9759,333 thousand tons. So the data of the accumulated waste in the region is given in fig. 2 .

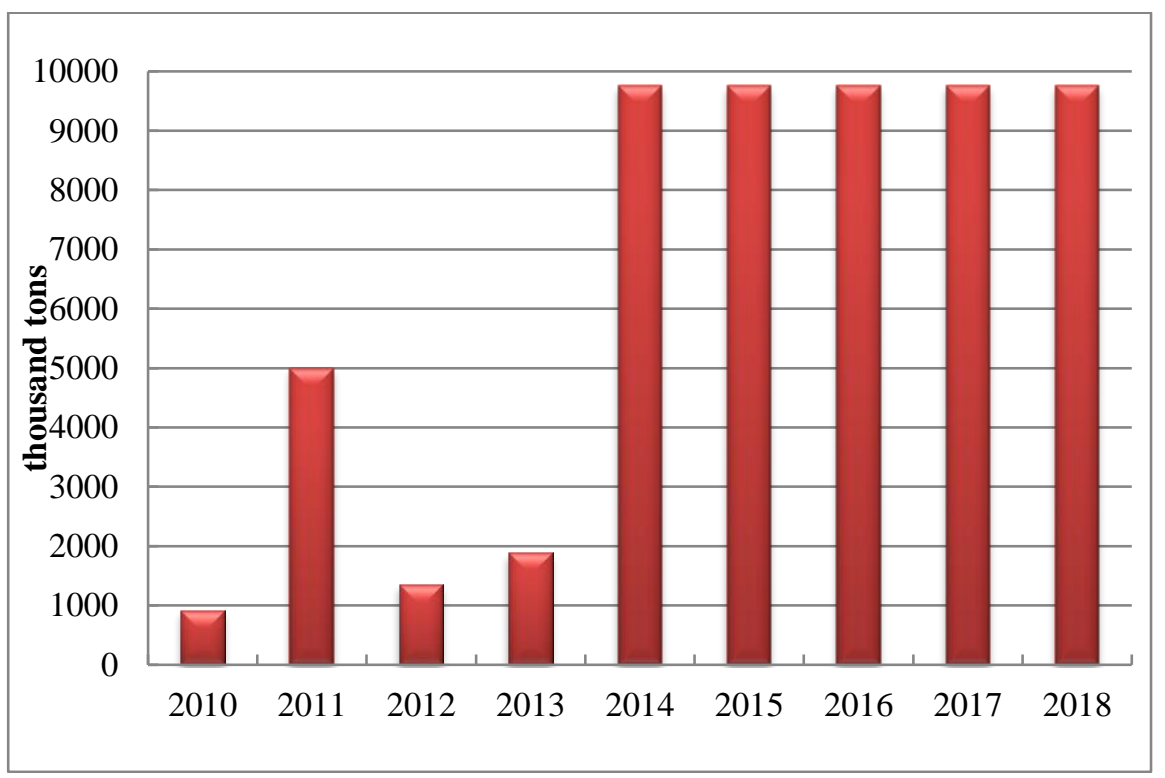

Fig. 2 - The volumes of accumulated waste in the Odessa region in 2010-2018

Taking into account the data on the area of the region the calculation of the $M_{G E}$ indicator was performed (Fig. 3). The analysis shows that the value of the $M_{G E}$ by the amount of the accumulated waste significantly exceeds the corresponding value by the amount of the generated waste. Since 2011 there has been a significant increase in a technogenic load on the GE by a total amount of waste in the region.

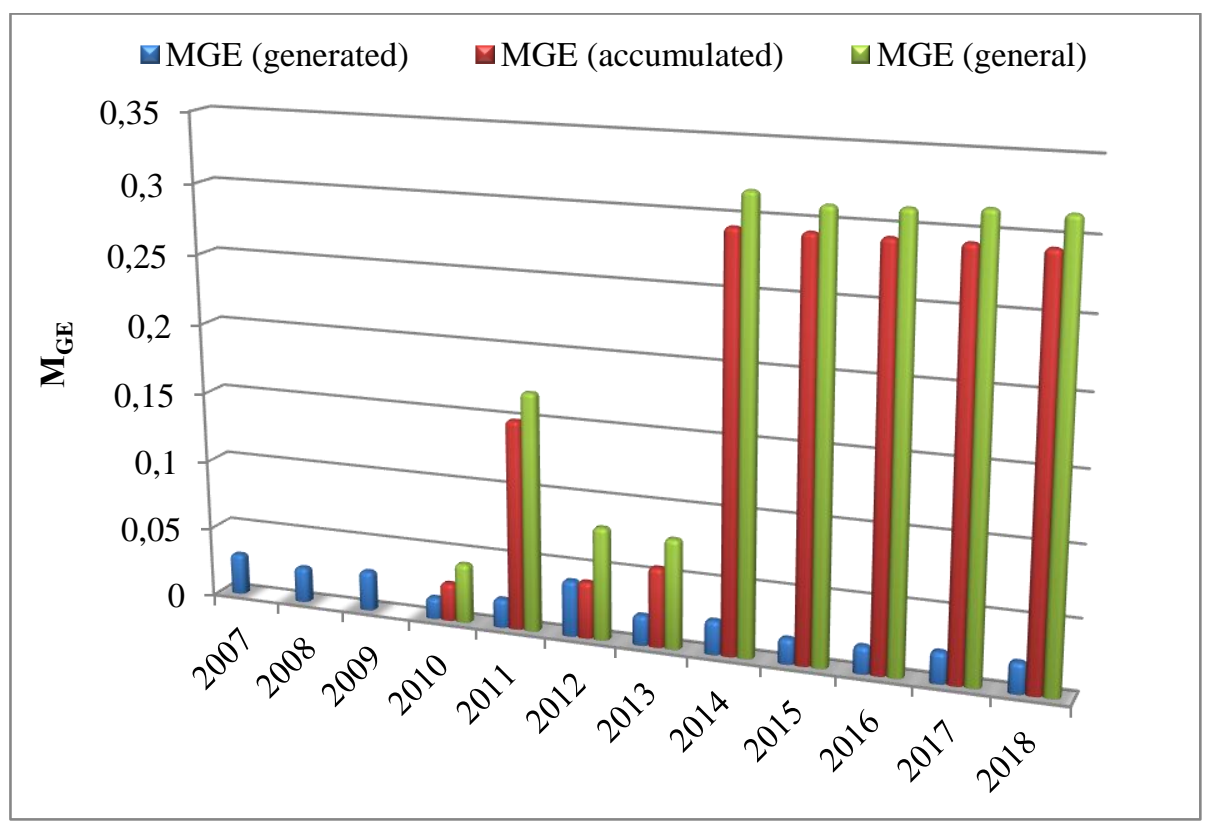

Fig. 3 - The value of the $M_{G E}$ indicator in the of Odessa region in 2007-2018 
Figure 4 shows the dynamics of the waste generation in the Mykolaiv region. It should be noted that in 2018, only a total amount of generated waste was available. Considering that in 2012-2017 the class IV waste generation was $96 \%$ on average, this figure was taken into account when calculating the estimated amount of this waste class in 2018.

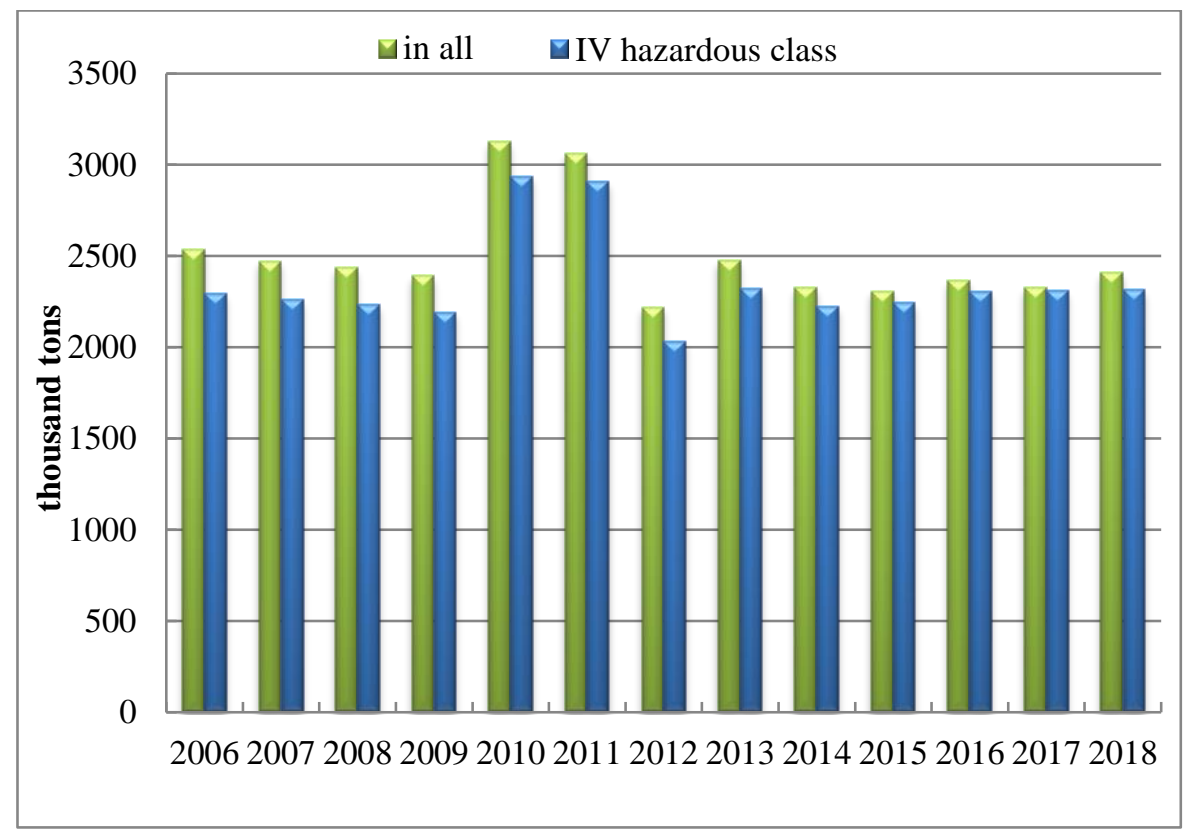

Fig. 4 - The dynamics of the waste generation in the Mykolaiv region in 2006-2018

The figure shows that the amount of annually generated waste in the Mykolaiv region does not exceed 2500 thousand tons/year. Two highs were indicated in 2010 2011, when the amount of generated waste exceeded 3000 thousand tons/year. The class IV hazardous waste is prevalent in the generated waste in the region. Its total amount ranges from 90 to $99 \%$ in recent years.

The data on the accumulated waste in the Mykolaiv region have been available since 2010 (Fig. 5). It can be seen that the amount of the accumulated waste in the region is much higher than the corresponding generated waste. There is also a steady tendency to increase the accumulated waste in the region.

Figure 6 shows the results of the calculation of the $M_{G E}$ indicator by the amount of the generated and accumulated waste in the Mykolayiv region. The figure shows that since 2011 there has been a steady tendency to increase a technogenic load on the GE by the amount of waste, primarily due to the increase of the accumulated waste.

Similar calculations were also made for the Kherson region. Figure 7 shows the dynamics of changes in the amount of the waste generation in the Kherson region. It should be noted that the actual data were not available in some years. Therefore they were interpolated taking into account the existing dependencies. Thus a total amount of generated in 2010 waste (taking into account the actual increase in the amount in 2007-2009) and the amount of class IV hazardous waste in 2018 were determined (according to calculations in 2015-2017, this amount averaged 89\% of the total waste). 


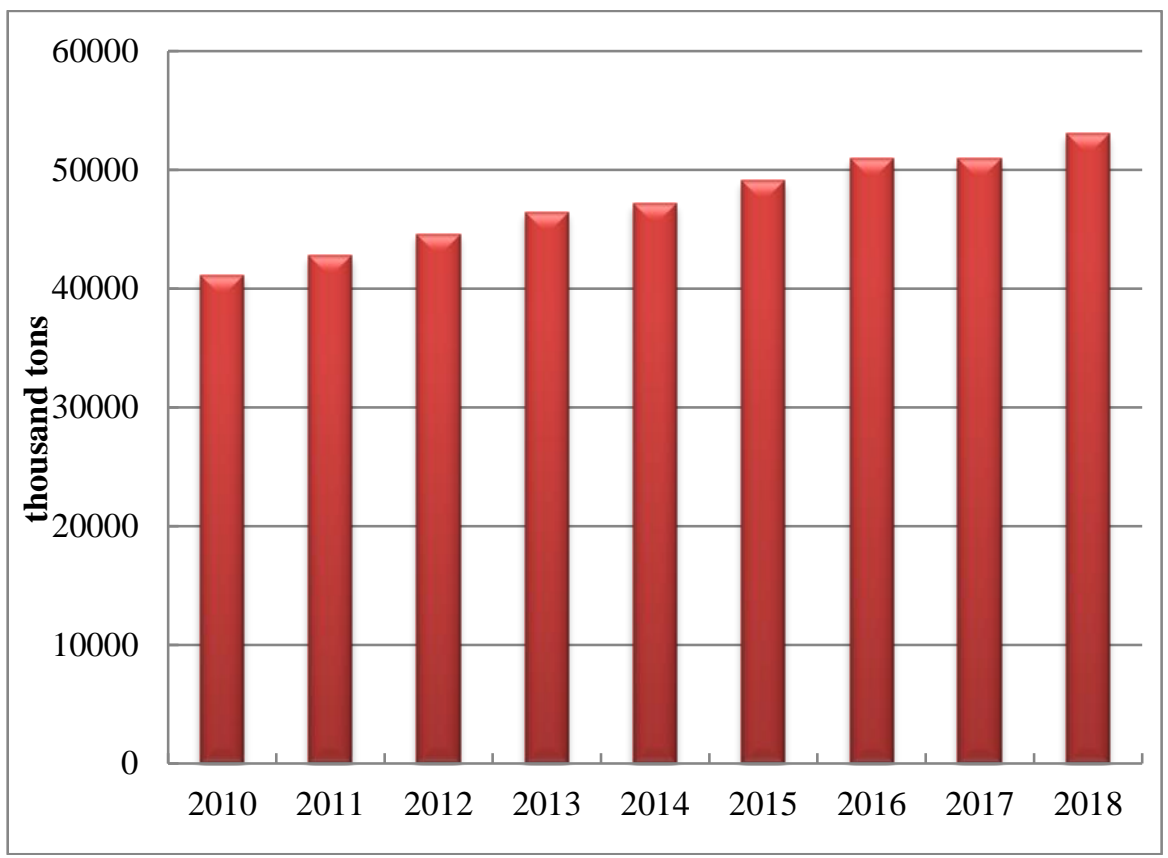

Fig. 5 - The volumes of the accumulated waste in the Mykolaiv region in 2010-2018

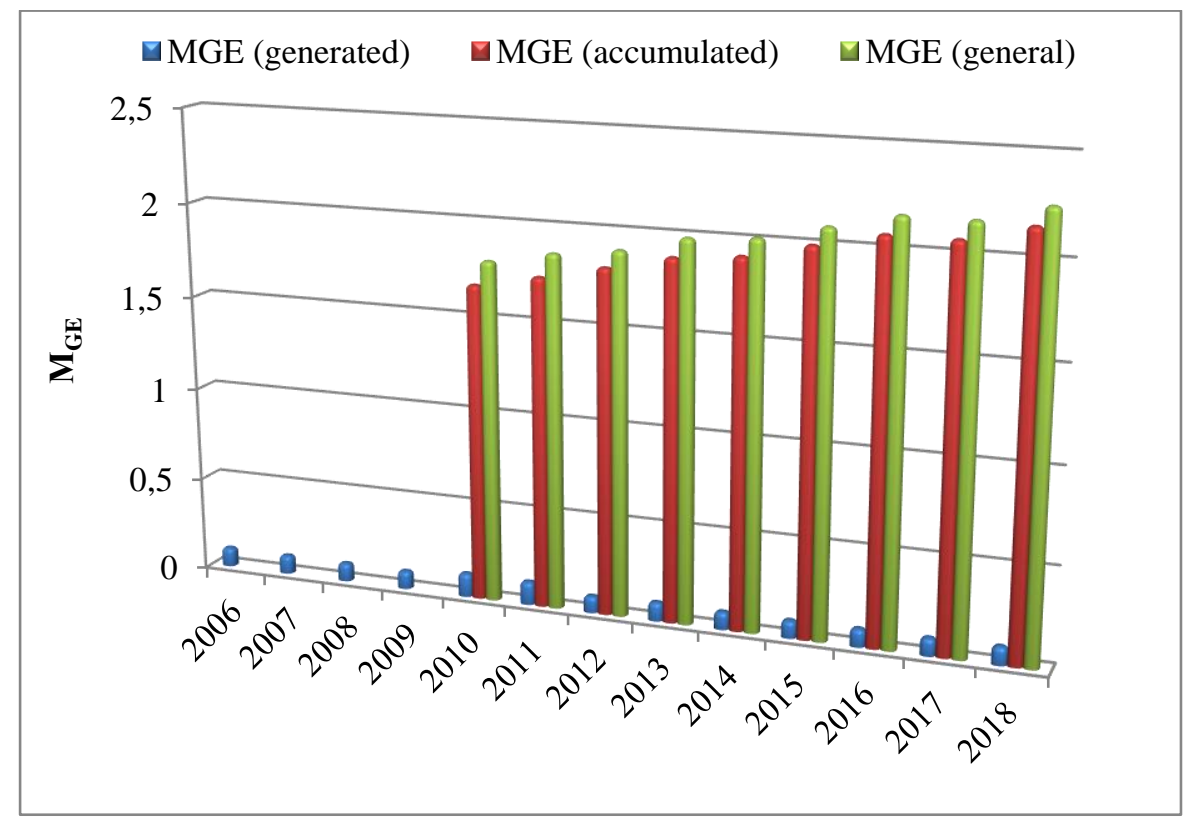

Fig. 6 - The values of the $M_{G E}$ indicator of the Mykolaiv region in 2006-2018

The figure above shows that the maximums of the waste generation in the region were observed in 2012-2014. Till 2012 there was a gradual significant increase in a total amount of the generated waste, in 2015-2018 there was a slight decrease. In recent years this value has hardly changed. Class IV waste is the predominant amount of the generated waste in all years. 


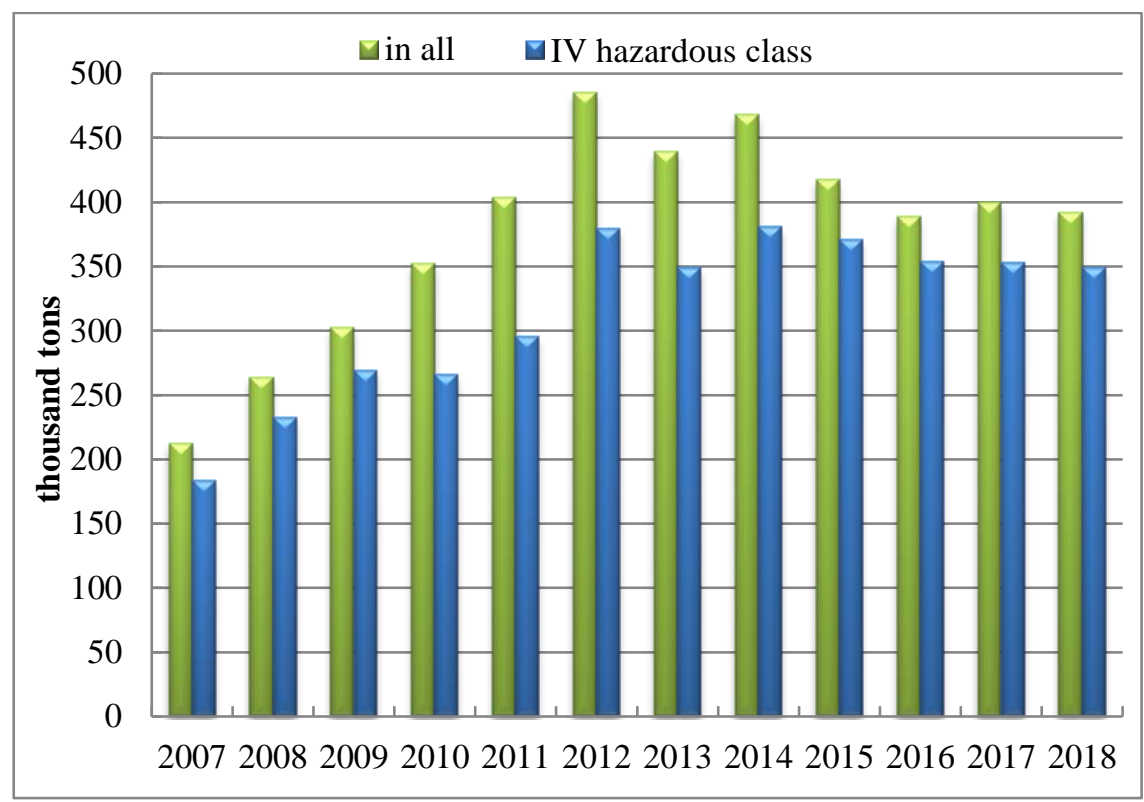

Fig. 7 - The dynamics of the waste generation in the Kherson region in 2007-2018

Information on the amount of the accumulated waste in the region (Fig. 8) has only been available since 2011, and the data for 2018 have also been interpolated considering the accumulation tendencies in recent years. As it can be seen, in 20112013 there was a sharp increase in the amount of the accumulated waste in the territory of the Kherson region (4 times). Since 2014 this tendency has continued, and in recent years the increase of the accumulated waste is up to 70 thousand tonnes annually. Also the amount of the accumulated waste in recent years is 3 times higher than the indicators for its generation. This is significantly lower than in other regions of the North-Western Black Sea, where the corresponding figures were different in order.

The $M_{G E}$ indicator was calculated based on the available data for the Kherson region. The results of the calculation are shown in Fig. 9.

The analysis of the given figure shows that with the constant increase of the accumulated waste in the territory of the Kherson region a level of a technogenic load on the GE of the region increases annually.

Comparative analysis showed (Fig. 10) that the maximum amount of waste among the North-Western Black Sea regions is generated in the Mykolaiv region (in different years $60-75 \%$ of a total amount of waste). The volume of the waste generation exceeds the order of magnitude in the Odessa and Kherson regions. The vast majority of waste in the Mykolaiv region is generated at the enterprise "The Mykolayiv Alumina Plant" (in 2018, this figure was almost 1800 thousand tons) [6]. Accordingly a level of a technogenic load on the GE in the Mykolaiv region is the highest among the regions of the North-Western Black Sea. A similar situation is noted by the indicators of the accumulated waste. In this case the volumes of the accumulated waste in the Mikolaev region (80-90\% as a whole in the North-Western Black Sea regions) are an order of magnitude higher than the corresponding indicators in the Odessa region and are two orders of magnitude in the Kherson region. 


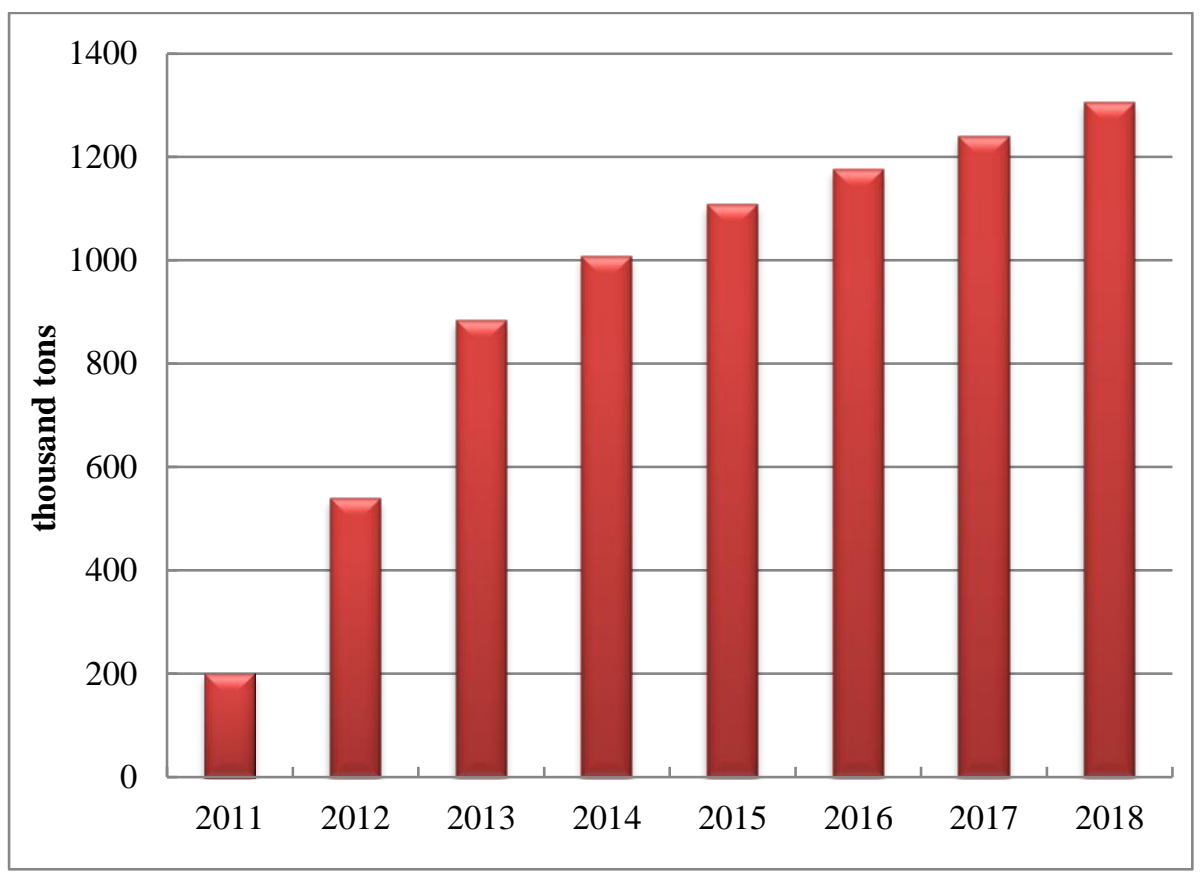

Fig. 8 - The volumes of the accumulated waste in the Kherson region in 2011-2018

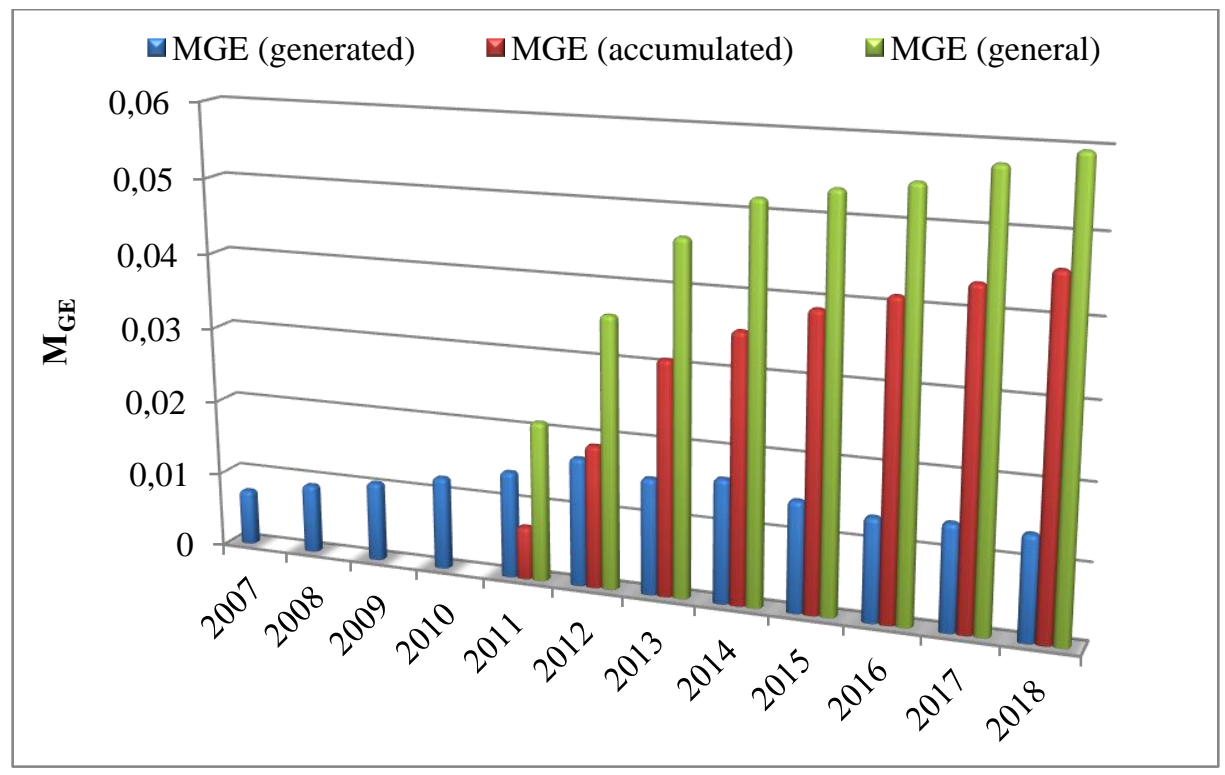

Fig. 9 - The value of the $M_{G E}$ indicator in the Kherson region in 2007-2018

\section{Conclusions}

The work assesses a level of a technogenic load on the GE by the indicators of forming and accumulating the production and consumption waste for the NorthWestern Black Sea regions. It is proposed to determine a module of a technogenic load on the GE. 
The performed studies have shown that in all the regions during the study period there is an increase in both forming and accumulating the waste. It is determined that the greatest load among the North-Western Black Sea regions is in the Mykolaiv

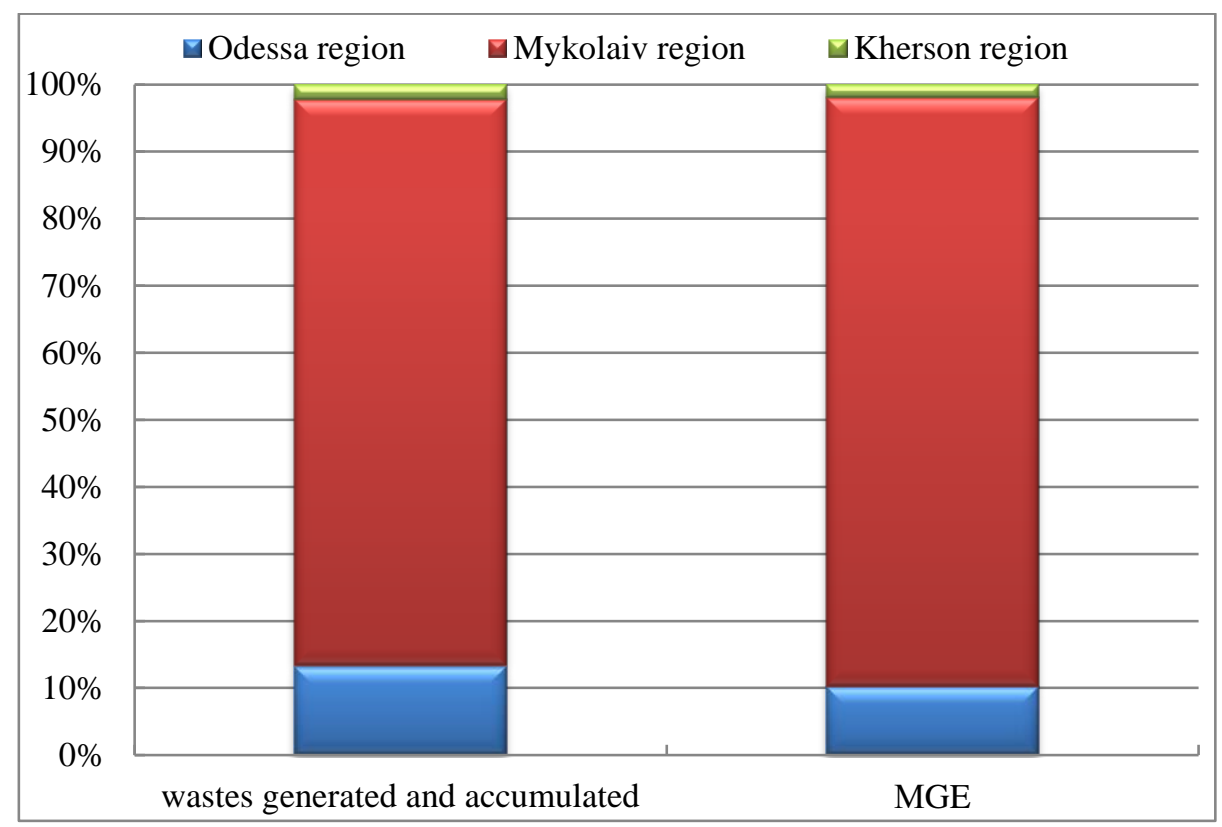

Fig. 10 - Comparative analysis of a level of a technogenic load on the GE of the North-Western Black Sea regions in 2003-2018

region (60-75\% of a total amount of the waste). The indicators of waste generation and accumulation exceed those in the Odessa and Kherson regions. More than $95 \%$ are class IV hazardous waste.

\section{REFERENCES}

1. Sergeev, E. M. (1979). Inzhenernaya geologiya - nauka o geologicheskoj srede [Engineering geology - the science of the geological environment]. Inzhenernaya geologiya, 1, 1-9. (in Russian)

2. Tolstoukhov, A. V. et al. Ekolohichna entsyklopediia: U 3 t. (2006 - V. 1, $2007-$ V. 2, 2008 - V. 3) [Ecological encyclopedia: 3 volumes]. Kyiv: TOV «Tsentr ekolohichnoi osvity ta informatsii». (in Ukrainian)

3. Trofimov, V. T. (Ed.). (1997). Teoriya i metodologiya ekologicheskoj geologii [Theory and methodology of environmental geology]. Moskow: Izd-vo MGU. (in Russian)

4. Rehionalna dopovid pro stan navkolyshnoho pryrodnoho seredovyshcha v Odeskii oblasti u 2018 rotsi [Regional Report on the State of the Environment in the Odessa Region in 2018]. (2019). Odessa. (in Ukrainian)

5. Safranov, T. A., Cherkez, Ye. A., \& Shatalin, S. M. (2018). Otsinka spryiatlyvosti terytorii Odeskoi oblasti dlia rozmishchennia polihoniv tverdykh pobutovykh vidkhodiv [Evaluation of the extent of favourableness of the territory of the Odesa region for placement of solid household waste landfills]. Ukrainskyi hidrometeorolohichnyi zhurnal, 21, 98-109. (in Ukrainian) 
6. Rehionalna dopovid pro stan navkolyshnoho pryrodnoho seredovyshcha v Mykolaivskii oblasti u 2018 rotsi [Regional report on the state of the environment in Mykolaiv region in 2018]. (2019). Mykolaiv. (in Ukrainian)

7. Rehionalna dopovid pro stan navkolyshnoho pryrodnoho seredovyshcha u Khersonskii oblasti u 2017 rotsi [Regional report on the state of the environment in the Kherson region in 2017]. (2018). Kherson. (in Ukrainian)

8. Safranov, T. A., Prykhodko, V. Iu., \& Shanina, T. P. (2016). Problema rozmishchennia vidkhodiv na zvalyshchakh ta polihonakh Odeskoi oblasti [The problem of waste disposal at landfills of Odessa region]. Visnyk KhNU im. V.N. Karazina, 14, 83-90. (in Ukrainian)

9. Safranov, T. A., Shanina, T. P., \& Prykhodko, V. Iu. (2017). Klasyfikatsiia nebezpechnoi skladovoi tverdykh pobutovykh vidkhodiv - peredumova formuvannia systemy povodzhennia $\mathrm{z}$ nymy $\mathrm{v}$ rehionakh Ukrainy [Classification of hazardous compound of municipal solid waste as a basis of its treatment system formation in regions of Ukraine]. Liudyna i dovkillia. Problemy neoekolohii, 1-2(27), 130-135. (in Ukrainian)

10. Elektronnyi resurs. URL: http://oblrada.odessa.gov.ua/wp-content/uploads/03-21VII.pdf (Retrieved: 12.02.2020).

11. Pryimak, V. V. (2016). Doslidzhennia problem utylizatsii ta povodzhennia z tverdymy pobutovymy vidkhodamy u Khersonskii oblasti [Research on problems of disposal and management of solid household waste in Kherson region]. Nauka i Studia, 10, 174-180. (in Ukrainian)

12. Pryimak, V. V. (2018). Doslidzhennia problem utylizatsii pobutovykh vidkhodiv u selakh (na prykladi s. Velyka Kardashynka Holoprystanskoho raionu) [Research on domestic waste disposal in rural areas (e.g., Velyka Cardashynka Gola Prystan District)]. Naukovi dopovidi NUBiP Ukrainy, 5(75). (in Ukrainian)

13. Safranov, T. A., \& Chuhai, A. V. (Eds.). (2017). Stan i yakist pryrodnoho seredovyshcha pryberezhnoi zony Pivnichno-Zakhidnoho Prychornomoria: monohrafiia [The state and quality of the natural environment of the coastal zone of the North-Western Black Sea]. Kharkiv: FOP Panov A.M. (in Ukrainian)

14. Adamenko, O. M., \& Rudko, H. I. (1998). Ekolohichna heolohiia [Environmental geology]. Kyiv: Manuskrypt. (in Ukrainian)

15. Chugai, A., Safranov, T., \& Holik, Yu. (2018). Analysis of the state of the air basin of industrial-urban agglomerations in the North-Western Black Sea. International Journal of Engineering \& Technology(UAE), 7(4.8), 783-789.

16. Chugai, A., \& Dzhura, O. (2019). Estimation of Technogenic Loading at the Surface Water of the North-Western Black Sea Coast Region. Environmental Problems, 4(4), 167173.

17. Elektronnyi resurs. URL: http://www.ukrstat.gov.ua/ (Retrieved: 19.01.2020).

The article was received 05.12.2019 and was accepted after revision 14.02.2020

\section{СПИСОК ЛІТЕРАТУРИ}

1. Сергеев Е.М. Инженерная геология - наука о геологической среде // Инженерная геология. 1979. № 1. С. 1-9.

2. Екологічна енциклопедія: У 3 т. // Толстоухов А.В. та ін. Київ: ТОВ «Центр екологічної освіти та інформації», 2006 - Т. 1, 2007 - Т. 2, 2008 - Т. 3.

3. Теория и методология экологической геологии // Под ред. Трофимова В.Т. Москва: Изд-во МГУ, 1997. 368 с.

4. Регіональна доповідь про стан навколишнього природного середовища в Одеській області у 2018 році. Одеса, 2019. 241 с.

5. Сафранов Т.А., Черкез Є.А., Шаталін С.М. Оцінка сприятливості території Одеської області для розміщення полігонів твердих побутових відходів // Український гідрометеорологічний журнал. 2018. № 21. С. 98-109. 
6. Регіональна доповідь про стан навколишнього природного середовища в Миколаївській області у 2018 році. Миколаїв, 2019. 175 с.

7. Регіональна доповідь про стан навколишнього природного середовища у Херсонській області у 2017 році. Херсон, 2018. 238 с.

8. Сафранов Т.А., Приходько В.Ю., Шаніна Т.П. Проблема розміщення відходів на звалищах та полігонах Одеської області // Вісник ХНУ ім. В.Н. Каразіна. 2016. Вип. 14. C. $83-90$.

9. Сафранов Т.А., Шаніна Т.П., Приходько В.Ю. Класифікація небезпечної складової твердих побутових відходів - передумова формування системи поводження з ними в регіонах України // Людина і довкілля. Проблеми неоекології. 2017. № 1 - 2 (27). C. $130-135$.

10. Електронний ресурс. URL: http://oblrada.odessa.gov.ua/wp-content/uploads/03-21VII.pdf (дата звернення: 12.02.2020).

11. Приймак В.В. Дослідження проблем утилізації та поводження 3 твердими побутовими відходами у Херсонській області // Nauka i Studia. 2016. T.10. C. 174-180. 12. Приймак В.В. Дослідження проблем утилізації побутових відходів у селах (на прикладі с. Велика Кардашинка Голопристанського району) // Наукові доповіді НУБіП України. 2018. № 5 (75).

13. Стан і якість природного середовища прибережної зони Північно-Західного Причорномор'я: монографія // За ред. Сафранова Т.А., Чугай А.В. Харків: ФОП Панов А.М., 2017. 298 с.

14. Адаменко О.М., Рудько Г.І. Екологічна геологія. Київ: Манускрипт, 1998. 348 с.

15. Chugai A., Safranov T., Holik Yu. Analysis of the state of the air basin of industrial-urban agglomerations in the North-Western Black Sea // International Journal of Engineering \& Technology(UAE). 2018. Vol. 7, No. 4.8. P. 783-789.

16. Chugai A., Dzhura O. Estimation of Technogenic Loading at the Surface Water of the North-Western Black Sea Coast Region // Environmental Problems. 2019. Vol. 4. Num. 4. P. 167-173.

17. Електронний ресурс. URL: http://www.ukrstat.gov.ua/ (дата звернення: 19.01.2020).

Стаття надійшла до редакиії 05.12.2019 і прийнята до друку після рецензування 14.02.2020

\section{А.В. Чугай, Т.А. Сафранов}

\section{ТЕХНОГЕННЕ НАВАНТАЖЕННЯ НА СКЛАДОВІ ДОВКІЛЛЯ ПРИ УТВОРЕННІ I НАКОПИЧЕННІ ВІДХОДІВ У РЕГІОНАХ ПІВНІЧНО- ЗАХІДНОГО ПРИЧОРНОМОР'Я}

Анотація. Одним із показників техногенного навантаження на складові довкілля можна розглядати кількість відходів виробництва і споживання, що утворюється і накопичується на певній території (в регіоні). Процеси утворення і накопичення різноманітних відходів несуть загрозу для стану всіх складових довкілля. При утворенні i, особливо, при накопиченні відходів виробництва і споживання неминуче відбувається забруднення грунтового покриву.

Проблема неефективного управління та поводження з відходами $є$ типовою для регіонів України, а тому метою роботи є оцінка рівня техногенного навантаження на складові довкілля за показниками утворення і накопичення відходів виробництва і споживання для регіонів Північно-Західного Причорномор'я. Для оцінки і аналізу рівня техногенного навантаження на довкілля на основі принципу розрахунку модуля техногенного навантаження запропоновано визначати модуль техногенного навантаження на геологічне середовище, тобто найбільш уразливої складової довкілля.

Встановлено, що найбільшого навантаження на території Північно-Західного Причорномор'я зазнає Миколаївська область (за рахунок промислових відходів). Кількість генерованих і накопичених відходів перевищують відповідні показники 
в Одеській і Херсонській областях. Більше 95\% складають відходи IV класу небезпеки. Майже у всіх регіонах Північно-Західного Причорномор'я відзначено тенденцію щодо збільшення навантаження, в першу чергу, через збільшення показників накопичення відходів.

Запропоновано визначати модуль техногенного навантаження на геологічне середовище за показниками відходів, що утворено і що накопичено в регіоні.

Ключові слова: модуль техногенного навантаження; геологічне середовище; відходи; утворення; накопичення

\section{Чугай Ангеліна Володимирівна}

кандидат географічних наук, доцент, декан природоохоронного факультету Одеського державного екологічного університету

Адреса робоча: 65016 Україна, м. Одеса, вул. Львівська, 15

e-mail: avchugai@ukr.net

ORCID: orcid.org/0000-0002-8091-8430

\section{Сафранов Тамерлан Абісалович}

доктор геолого-мінералогічних наук, професор, завідувач кафедри екології та охорони довкілля Одеського державного екологічного університету

Адреса робоча: 65016 Україна, м. Одеса, вул. Львівська, 15

e-mail: safranov@ukr.net

ORCID: orcid.org/0000-0003-0928-5121 